\title{
Analisis Tingkat Berfikir Kreatif Peserta Didik Dalam Menyelesaikan Soal Matematika Ditinjau Dari Adversity Quotient (AQ)
}

\author{
Duwi Asih ${ }^{1}$, I Ketut Suastika ${ }^{2}$, Nyamik Rahayu Sesanti ${ }^{3}$ \\ ${ }^{1}$ Program Studi Pendidikan Matematika, Universitas Kanjuruhan Malang \\ duwiasih14@gmail.com \\ ${ }^{2}$ Program Studi Pendidikan Matematika, Universitas Kanjuruhan Malang \\ suastika@unikama.ac.id \\ ${ }^{3}$ Program Studi Pendidikan Matematika, Universitas Kanjuruhan Malang \\ nyamik@unikama.ac.id
}

\begin{abstract}
ABSTRAK. The aim of this paper is to describe students' creative thinking abilities in solving problems in terms of Adversity Quotient (AQ). This study used a descriptive qualitative approach with questionnaire and test method. The subjects of this study were SMP Turen Muhammadiyah 10 class VIII, who were selected based on their Adversity Quotient (AQ). The results of this paper are (1) the questionnaire score of the Adversity Response Profile (ARP) shows 6 students with the type of quitters, 7 transitional type students between quitters to campers, 9 students with type campers, 6 students with transition types of campers to climbers, 4 students with type climbers. (2) The written test results showed students with AQ type climbers included in the "high" category, AQ type campers included as "low" category, AQ type quitters including "very low" level categories in creative thinking. Suggestions from this study are teachers are expected to provide exercises with various types of questions to improve students' creative thinking skills.
\end{abstract}

Keywords: Analize; cretive thinking; Adversity Quotient (AQ)

\begin{abstract}
ABSTRAK. Tujuan dari penelitian ini adalah untuk mendeskripsikan kemampuan berfikir kreatif peserta didik dalam menyelesaikan masalah ditinjau dari Adversity Quotient (AQ). Penelitian ini menggunakan pendekatan kualitatif yang bersifat deskriptif dengan metode angket, tes. Subyek penelitian ini adalah peserta didik kelas VIII SMP Muhammadiyah 10 Turen yang dipilih berdasarkan Adversity Quotient (AQ) secara acak. Hasil penelitian ini yaitu (1) skor angket Adversity Respone Profile (ARP) menunjukkan 6 peserta didik dengan tipe quitters, 7 peserta didik dengan tipe peralihan antara quitters ke campers, 9 peserta didik dengan tipe campers, 6 peserta didik dengan tipe peralihan campers ke climbers, 4 peserta didik dengan tipe climbers. (2) Hasil tes tulis menunjukkan peserta didik dengan AQ tipe climbers termasuk kategori tingkat "tinggi", AQ tipe campers termasuk kategori tingkat "rendah", AQ tipe quitters termasuk kategori tingkat "sangat rendah" dalam berfikir kreatif. Saran dari penelitian ini adalah guru diharapkan memberikan latihan-latihan dengan berbagai jenis soal untuk meningkatkan kemampuan berfikir kreatif peserta didik.
\end{abstract}

Kata Kunci: Analisis; berfikir kreatif; Adversity Quotient (AQ)

\section{Pendahuluan}

Orientasi pembelajaran matematika saat ini diupayakan lebih menekankan pada pengajaran untuk meningkatkan cara berfikir kreatif peserta didik. Menurut Lindren (dalam Yamin, 2013:127) berfikir kreatif yaitu memberikan macam-macam kemungkinan jawaban atau pemecahan masalah berdasarkan informasi,yang diberikan dan mencetuskan banyak gagasan terhadap suatu persoalan. Ada beberapa alasan mengapa pembelajaran matematika perlu menekankan pada berfikir kreatif, yaitu : (1) matematika begitu kompleks dan luas untuk diajarkan dengan cara hafalan, (2) peserta didik dapat menemukan solusi-solusi yang berbeda saat mengerjakan soal, (3) pembelajaran matematika dengan hafalan membuat peserta didik kurang termotivasi dan mengurangi kemampuan berfikir kreatif, (4) keaslian merupakan sesuatu yang perlu diajarkan seperti membuat pembuktian dari teorema-teorema dalam matematika.

Berfikir kreatif peserta didik dapat terlihat dari bagaimana peserta didik menyelesaikan setiap permasalahan yang dihadapi. Hal ini dapat dilihat dari bagaimana cara peserta didik menyelesaikan suatu soal matematika dengan berbagai cara yang berbeda namun itu tidak bertolak belakang dengan cara yang sudah ada sebelumnya (Alhabbah, 
2015:7). Kattou (dalam Suastika 2016) melaporkan bahwa aspek berfikir kreatif yang diukur dalam memecahkan masalah matematika adalah fluency, flexibility and originality. Silver (dalam Siswono 2011) mengemukakan bahwa berfikir kreatif dapat dirumuskan sebagai kemampuan yang mencerminkan aspek-aspek kelancaran (fluency), keluwesan (flexibility), dan kebaruan (novelty) dalam berfikir. Menurut Siswono (2008:61) dalam berfikir kreatif, seseorang akan melalui tahapan mensintesis ide, membangun ide, merencanakan penerapan ide, dan menerapkan ide tersebut sehingga menghasilkan produk yang baru.

Kenyataannya proses berfikir kreatif peserta didik dalam matematika belum diperhatikan oleh guru. Berdasarkan hasil observasi pada SMP Muhammadiyah 10 Turen, kegiatan pembelajaran sudah difokuskan pada peserta didik. Peserta didik dibentuk dalam kelompok belajar dan bertanggung jawab atas LKPD yang diberikan guru, namun soal yang diberikan sebatas pada materi yang diajarkan yang telah didahului dengan contoh oleh guru. Pemberian soal rutin seperti itu membuat peserta didik hanya menguasai teknik penyelesaian yang sudah dicontohkan sebelumnya dan tidak memberikan ruang bagi peserta didik untuk berkreasi dengan pengalaman sebelumnya. Sehingga peserta didik kurang dalam hal berfikir kreatif untuk menyelesaikan soal matematika.

Stoltz (dalam Ningrum 2016) menyatakan bahwa orang yang tidak mampu mengahadapi kesulitan akan menjadi orang yang tidak mampu bertindak kreatif, untuk melihat tingkat berfikir kreatif seseorang dapat dikaitkan dengan Adversity Quotient (AQ) karena melalui AQ seseorang, kita dapat mengetahui bagaimana tingkat berfikir kreatif seseorang. Agustian (dalam Supardi) mengungkapkan bahwa Adversity Quotient (AQ) adalah kecerdasan yang dimiliki seseorang dalam mengatasi kesulitan dan bertahan hidup. Adversity Quotient (AQ) dapat diartikan sebagai ukuran untuk mengetahui respons seseorang dalam menghadapi kesulitan. Adversity Quotient (AQ) memberitahu seberapa jauh seseorang mampu bertahan dalam menghadapi kesulitan dan seberapa jauh kemampuannya untuk mengatasi kesulitan tersebut (Budiarto, 2017).

Stoltz (dalam Ningrum 2016) memaparkan ada tiga kategori dalam Adversity Quotient yang dapat kita temui yaitu : (1) Kategori AQ Climbers yaitu kategori yang tidak mudah menyerah dalam mengahadapi suatu kendala, ia akan terus berusaha untuk menemukan solusi dari masalah tersebut; (2) Kategori AQ Campers yaitu kategori yang memiliki kemauan untuk menyelesaikan masalah tetapi jika dalam penyelesaiannya menemukan hambatan mereka tidak mau berusaha lebih keras; (3) Kategori AQ Quitters yaitu kategori yang tidak mau berusaha mencari penyelesaian masalah yang dihadapi, sehingga tidak mampu menunjukkan ide kreatifnya dalam menyelesaikan masalah. Jadi peserta didik dengan kategori Climbers akan memiliki cara berfikir kreatif paling tinggi di antara ketiga kategori AQ, disusul dengan peserta didik dengan kategori AQ Campers kemudian AQ Quitters. Stoltz (dalam Fauziah 2013) telah menyebutkan AQ terdiri dari empat dimensi yaitu CO2RE. CO2RE adalah akronim dari control (kendali), origin \& ownership (asal usul dan pengakuan), reach (jangkauan) dan endurance (daya tahan).

Berdasarkan uraian di atas peneliti tertarik untuk melakukan penelitian dengan judul analisis tingkat berfikir kreatif peserta didik dalam menyelesaikan soal matematika ditinjau dari Adversity Quotient (AQ).

\section{METODE}

Jenis penelitian yang digunakan adalah penelitian kualitatif yang bersifat deskriptif. Penelitian kualitatif memiliki ciri-ciri yaitu mempunyai latar belakang alamiah (konteks dari suatu keutuhan), manusia sebagai alat atau instrumen, menggunakan metode kualitatif, analisis data secara induktif, penyusunan teori berdasarkan data, data bersifat deskriptif, lebih mementingkan proses daripada hasil, adanya batas yang ditentukan oleh fokus, adanya kriteria khusus untuk keabsahan data, desain bersifat sementara, dan hasil penelitian merupakan hasil keputusan bersama (Moleong, 2011). Lokasi yang digunakan dalam penelitian ini adalah di SMP Muhammadiyah 10 Turen. Subyek dalam penelitian ini adalah peserta didik kelas VIII SMP Muhammadiyah 10 Turen. Dalam penelitian kualitatif peneliti berperan sebagai instrumen utama dalam menetapkan fokus penelitian, memilih informasi sebagai sumber data, melakukan pengumpulan data, menafsirkan data dan membuat kesimpulan atas temuan yang diperoleh (Sugiyono, 2009). Berikut prosedur dalam pengumpulan data pada penelitian ini yaitu :

1. Metode Kuesioner (Angket)

Kuesinoner merupakan teknik pengumpulan data yang dilakukan dengan cara memberikan seperangkat pertanyaan atau pernyataan tertulis kepada responden untuk dijawab (Diana, 2010). Metode angket ini digunakan untuk mengumpulkan data mengenai skor Adversity Quotient (AQ) peserta didik. Instrumen yang digunakan untuk mengukur Adversity Quotient (AQ) peserta didik disebut Adversity Response Profile (Profil Respons terhadap Kesulitan) yang terdiri dari 40 pernyataan.

Skala yang digunakan dalam instrumen ini adalah skala Likert, kategori respon terdiri dari lima alternatif jawaban yang meliputi: sangat setuju (SS); setuju (S); biasa saja (BS); tidak setuju (TS); dan sangat tidak setuju (STS). Setiap pernyataan yang bersifat positif diberi skor secara berurutan yaitu 5,4,3,2,1, dan sebaliknya bila pernyataan bersifat negatif diberi skor secara berurutan yaitu 1,2,3,4,5. Pernyataan yang digunakan menyesuaikan keadaan dan bahasa dari subyek penelitian yaitu peserta didik yang tengah menempuh pendidikan di sekolah menengah pertama.

2. Tes Kemampuan Berfikir Kreatif Peserta Didik

Prosedur tes kemampuan berfikir kreatif merupakan prosedur pengumpulan data berupa pemberian kumpulan soal-soal yang digunakan untuk memberikan gambaran kemampuan berfikir kreatif peserta didik.

Jenis analisis data yang digunakan dalam penelitian itu adalah analisis data model Miles dan Huberman. Aktivitas

Copyright $(\odot 2018$ Author [s]. This is an open-access article distributed under the terms of the Creative Commons Attribution License (CC BY). The use,

distribution or reproduction in other forums is permitted, provided the original author(s) and the copyright owner(s) are credited and that the original

publication in this journal is cited, in accordance with accepted academic practice. No use, distribution or reproduction is permitted which does not comply with these terms. 
36|P a g e

dalam analisis data meliputi:

a. Reduksi data yaitu data yang diperoleh dari hasil angket disusun dalam bentuk skor total dari semua dimensi AQ yang akhirnya diperoleh temuan sesuai tujuan yang akan dicapai dengan pengkategorian tipe-tipe peserta didik berdasarkan AQ.

Teknik perhitungan Adversity Quotient dengan menggunakan rumus sebagai berikut :

$\mathrm{AQ}=\mathrm{C}+\mathrm{O} \_2+\mathrm{R}+\mathrm{E}$

Dari hasil tes ARP sebagai penentu tipe-tipe Adversity Quotient dipilih subyek untuk mengerjakan tes tulis. Pemilihan subyek ini didasarkan pada 50\% dari jumlah subyek pada tiap kategori climbers, campers, quitters.

b. Penyajian data

c. Proses penarikan kesimpulan.

Tabel 1 Pengkategorian Peserta Didik berdasarkan Hasil Angket AQ

\begin{tabular}{cc}
\hline Kisaran Skor & Tipe AQ \\
\hline $166 \leq \mathrm{AQ} \leq 200$ & Climbers \\
\hline $135 \leq \mathrm{AQ} \leq 165$ & Peralihan Campers ke Climbers \\
\hline $95 \leq \mathrm{AQ} \leq 134$ & Campers \\
\hline $60 \leq \mathrm{AQ} \leq 94$ & Peralihan Quitters ke Campers \\
\hline $0 \leq \mathrm{AQ} \leq 59$ & Quitters \\
\hline
\end{tabular}

Sumber : Stoltz (dalam Diana 2009)

Tabel 2 Kategori Berfikir Kreatif Peserta Didik

\begin{tabular}{lc}
\hline \multicolumn{1}{c}{ Skor Berfikir Kreatif $(\mathrm{Kr})$} & Kategori Berfikir Kreatif $(\mathrm{Kr})$ \\
\hline$K r \geq 3,25$ & Sangat Tinggi \\
\hline $2,25 \leq K r<3,25$ & Tinggi \\
\hline $1,25 \leq K r<2,25$ & Rendah \\
\hline$K r<1,25$ & Sangat Rendah \\
\hline
\end{tabular}

Sumber : Suastika (2016)

\section{Hasil dan Pembahasan}

Berdasarkan hasil angket ARP dari 32 peserta didik terdapat 6 peserta didik yang masuk dalam tipe quitters dengan rentang skor AQ antara $0-59,7$ peserta didik yang masuk dalam tipe peralihan antara quitters ke campers dengan rentang skor AQ antara 60-94, 9 peserta didik yang masuk dalam tipe campers dengan rentang skor AQ antara 95-134, 6 peserta didik yang masuk dalam tipe peralihan antara campers ke climbers dengan rentang skor AQ antara 135-165, dan 4 peserta didik yang masuk dalam tipe climbers dengan rentang skor AQ antara 166-200. Meskipun pada hasil skor ARP menunjukkan bahwa terdapat 7 peserta didik yang masuk dalam tipe peralihan antara quitters ke campers serta 6 peserta didik yang masuk dalam tipe peralihan antara campers ke climbers, namun pada penelitian ini hanya dibatasi pada tipe AQ quitters, campers dan climbers.

Dari 32 peserta didik yang telah melakukan tes Adversity Response Profile (ARP) dipilih subyek analisis 10 peserta didik kelas VIII SMP Muhammadiyah 10 Turen dengan rincian masing-masing kelompok terdiri dari 3 peserta didik tipe quitters yaitu subyek VM, GTR, SA, 5 peserta didik tipe campers yaitu subyek SJP, SW, ASJ, AV, dan AB, 2 peserta didik tipe climbers yaitu subyek SA dan NA. Pemilihan subyek ini didasarkan pada 50\% dari jumlah peserta didik pada tipe climbers, campers dan quitters. Berikut ini disajikan hasil tes tulis peserta didik.

Tabel 3 Hasil Tes Tulis Berfikir Kreatif

\begin{tabular}{cccc}
\hline Tipe AQ & $\begin{array}{c}\text { Kode } \\
\text { Subyek }\end{array}$ & $\begin{array}{c}\text { Skor Berfikir } \\
\text { Kreatif }(\mathrm{Kr})\end{array}$ & $\begin{array}{c}\text { Kategori dalam } \\
\text { Berfikir Kreatif }\end{array}$ \\
\hline \multirow{2}{*}{ Climbers } & SKA & 2,67 & Tinggi \\
\cline { 2 - 4 } & NA & 2,83 & Tinggi \\
\hline \multirow{4}{*}{ Campers } & SJP & 1,67 & Rendah \\
\cline { 2 - 4 } & SW & 1,83 & Rendah \\
\cline { 2 - 4 } & ASJ & 1,50 & Rendah \\
\cline { 2 - 4 } & $\mathrm{AV}$ & 1,50 & Rendah \\
\cline { 2 - 4 } Quitters & $\mathrm{AB}$ & 1,50 & Rendah \\
\cline { 2 - 4 } & $\mathrm{VM}$ & 0,83 & Sangat Rendah \\
\cline { 2 - 4 } & $\mathrm{GTR}$ & 0,50 & Sangat Rendah \\
\cline { 2 - 4 } & $\mathrm{SA}$ & 0,50 & Sangat Rendah \\
\hline
\end{tabular}

\section{Hasil Tes Tulis}

\section{Subyek NA yang mewakili tipe AQ}

Copyright (@) 2018 Author [s]. This is an open-access article distributed distribution or reproduction in other forums is permitted, provided th

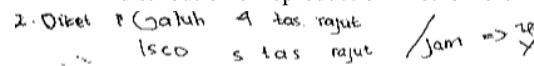

$4 u+5 y=29 \rightarrow x=20-y$

$x+y=20 \quad 4 x+5 y=89-24(20-y)+5 y=89$
$80-4 y+5 y=89$ $80+y=89$

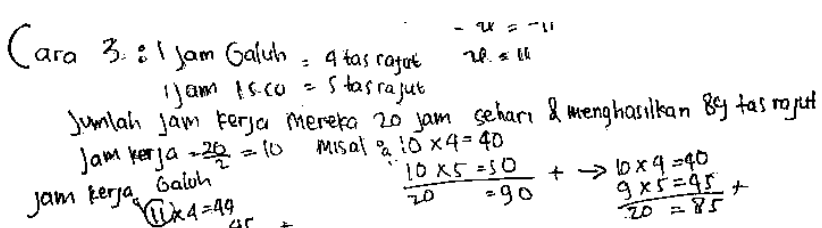




\section{Climbers}

\section{Gambar 1 Hasil Tes Tulis Subyek NA Soal Nomor 2}

Subyek NA mampu memberikan tiga jawaban dengan hasil benar. Sehingga dapat dikatakan subyek NA mampu dalam mengerjakan soal nomor 2 pada indikator kelancaran. Subyek NA mampu memahami soal dengan baik dan dapat memberikan tiga alternatif penyelesaian dengan hasil yang benar. Sehingga dapat dikatakan subyek NA mampu dalam mengerjakan soal nomor 2 pada indikator keluwesan. Subyek NA cukup mampu mengerjakan soal dengan caranya sendiri yaitu dengan tidak menggunakan metode eliminasi, grafik maupun substitusi, subyek NA menggunakan pengandaian untuk menemukan hasil akhir, cara yang dipakai cukup bisa dimengerti dan dipahami oleh peneliti. Sehingga dapat dikatakan subyek NA mampu dalam mengerjakan soal nomor 2 pada indikator kebaruan.

Subyek ASJ yang mewakili tipe AQ Campers

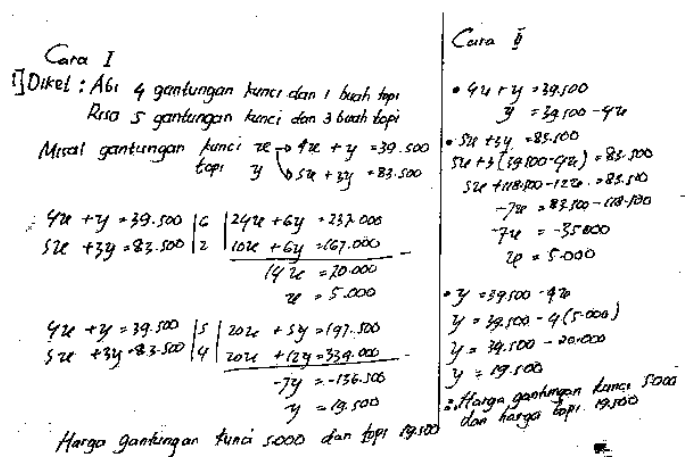

Gambar 2 Hasil Tes Tulis Subyek ASJ Soal Nomor 1

Subyek ASJ mampu memberikan dua jawaban dengan hasil benar. Sehingga dapat dikatakan subyek ASJ mampu dalam mengerjakan soal nomor 1 pada indikator kelancaran. Subyek ASJ dapat memberikan dua alternatif penyelesaian dengan hasil benar. Subyek ASJ menggunakan metode substitusi dan metode eliminasi. Sehingga dapat dikatakan subyek ASJ mampu dalam mengerjakan soal nomor 1 pada indikator keluwesan. Subyek ASJ belum mampu mengerjakan soal dengan caranya sendiri karena subyek ASJ masih menggunakan cara yang biasa digunakan dalam penyelesaian soal SPLDV yaitu menggunakan cara substitusi dan cara eliminasi. Sehingga dapat dikatakan subyek ASJ belum mampu dalam mengerjakan soal nomor 1 pada indikator kebaruan.

\section{Subyek SA yang mewakili tipe AQ Quitters}

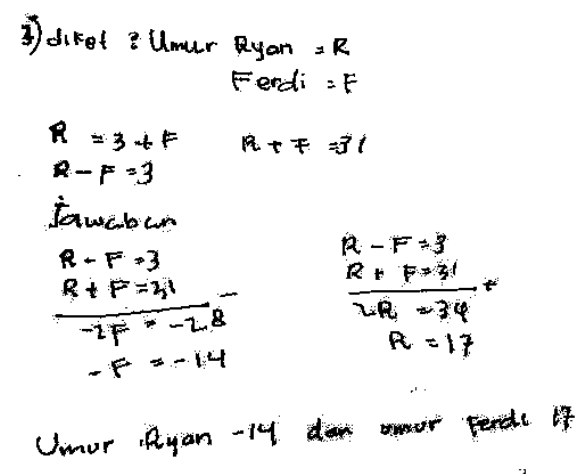

Gambar 3 Hasil Tes Tulis Subyek SA Soal Nomor 3

Subyek SA tidak mampu memberikan jawaban dengan benar. Sehingga dapat dikatakan subyek SA tidak mampu

Copyright $\odot 2018$ Author [s]. This is an open-access article distributed under the terms of the Creative Commons Attribution License (CC BY). The use, distribution or reproduction in other forums is permitted, provided the original author(s) and the copyright owner(s) are credited and that the original publication in this journal is cited, in accordance with accepted academic practice. No use, distribution or reproduction is permitted which does not comply with these terms. 
dalam mengerjakan soal nomor 3 pada indikator kelancaran. Subyek SA cukup mampu dalam memahami soal yang diberikan terlihat dari persamaan yang ditulis namun dalam proses pengerjaan dalam mengoperasikan tanda bilangan subyek SA kurang teliti sehingga hasil akhir salah. Subyek menggunakan metode eliminasi, pada proses menntukan nilai $\mathrm{F}$ subyek kurang teliti harusnya nilai $\mathrm{F}=14$ bukan $-\mathrm{F}=-14$ Sehingga dapat dikatakan subyek SA tidak mampu dalam mengerjakan soal nomor 3 pada indikator keluwesan. Subyek SA tidak mampu mengerjakan soal dengan caranya sendiri karena subyek SA menggunakan metode eliminasi namun hasilnya salah. Sehingga dapat dikatakan subyek SA tidak mampu dalam mengerjakan soal nomor 3 pada indikator kebaruan.

\section{PEMBAHASAN}

A. Tingkat berfikir kreatif peserta didik dengan AQ tipe climbers

Berdasarkan data yang diperoleh dari hasil angket ARP terdapat 4 subyek yang termasuk dalam AQ tipe climbers. Sesuai dengan teori Stoltz (dalam Ningrum 2016) yang mengungkapkan bahwa tipe AQ Climbers yaitu tipe yang tidak mudah menyerah dalam menghadapi suatu kendala, ia akan terus berusaha untuk menemukan solusi dari masalah tersebut. Peserta didik dengan AQ tipe Climbers mempunyai semangat yang tinggi dalam mengerjakan soal matematika, berusaha berjuang mencari jawaban soal tersebut. Hal ini terlihat dari hasil tes tulis dan wawancara subyek SKA dan NA yang memenuhi aspek kelancaran (fluency), aspek keluwesan (flexibility), dan aspek kebaruan (novelty). Peserta didik dengan AQ tipe climbers mampu memberikan dan menjelaskan hasil pekerjaannya yang telah ditulis dengan lancar dan benar pada soal yang diberikan, peserta didik mampu memberikan dan menjelaskan beberapa alternatif jawaban yang ditulis, peserta didik mampu memberikan jawaban menggunakan caranya sendiri dengan tidak menggunakan metode yang biasa digunakan dalam menyelesaikan soal SPLDV (grafik, eliminasi, substitusi). Skor yang diperoleh subyek dalam tes tulis berkisar 2,25 $\leq \mathrm{Kr}<3,25$ sehingga dalam hal ini peserta didik termasuk kategori tingkat "tinggi" dalam berfikir kreatif.

B. Tingkat berfikir kreatif peserta didik dengan AQ tipe campers

Berdasarkan data yang diperoleh dari hasil angket ARP terdapat 9 subyek yang termasuk dalam AQ tipe campers. Sesuai dengan teori Stoltz (dalam Ningrum 2016) yang mengungkapkan bahwa tipe AQ campers yaitu tipe yang memiliki kemauan untuk menyelesaikan masalah tetapi jika dalam penyelesaiannya menemukan hambatan atau kendala mereka tidak mau berusaha lebih keras. Peserta didik dengan AQ tipe Campers mempunyai sedikit semangat, memperlihatkan inisiatif dalam mengerjakan soal, dan masih mau berusaha mengerjakan soal untuk mendapatkan jawabannya. Peserta didik dengan AQ tipe campers mampu memberikan dan menjelaskan hasil pekerjaannya yang telah ditulis dengan lancar dan benar pada soal yang diberikan, peserta didik ada yang mampu dan ada yang tidak mampu memberikan dan menjelaskan beberapa alternatif jawaban yang ditulis, peserta didik ada yang mampu dan tidak mampu dalam memberikan jawaban menggunakan caranya sendiri dengan tidak menggunakan metode yang biasa digunakan dalam menyelesaikan soal SPLDV (grafik, eliminasi, substitusi). Hal ini terlihat dari hasil tes tulis dan wawancara subyek SJP, SW, ASJ, AV dan AB yang hanya beberapa dari subyek memenuhi aspek kelancaran (fluency), aspek keluwesan (flexibility), dan aspek kebaruan (novelty). Skor yang diperoleh subyek dalam tes tulis berkisar $1,25 \leq \mathrm{Kr}<2,25$ sehingga dalam hal ini peserta didik termasuk kategori tingkat "rendah" dalam berfikir kreatif. Berikut ini diuraikan hasil tes tulis subyek dengan tipe campers pada kategori tingkat "rendah" dalam berfikir kreatif.

C. Tingkat berfikir kreatif peserta didik dengan AQ tipe quitters

Berdasarkan data yang diperoleh dari hasil angket ARP terdapat 6 subyek yang termasuk dalam AQ tipe quitters. Sesuai dengan teori Stoltz (dalam Ningrum 2016) yang mengungkapkan bahwa tipe AQ quitters yaitu tipe yang tidak mau berusaha mencari penyelesaian dari masalah yang dihadapi, sehingga tidak mampu menunjukkan ide kreatifnya dalam menyelesaikan masalah. Peserta didik dengan AQ tipe Quitters tidak mempunyai semangat dalam mengerjakan soal karena menganggap matematika terlalu sulit, tidak mau mengambil resiko sehingga tidak mengerjakan dengan baik, tidak mau berusaha untuk menyelesaikan dan menemukan jawaban. Peserta didik dengan AQ tipe quitters ada yang mampu dan ada yang tidak mampu menjelaskan hasil pekerjaannya yang telah ditulis dengan lancar dan benar pada soal yang diberikan, peserta didik ada yang mampu dan ada yang tidak mampu memberikan dan menjelaskan beberapa alternatif jawaban yang ditulis, peserta didik tidak mampu dalam memberikan jawaban menggunakan caranya sendiri dengan tidak menggunakan metode yang biasa digunakan dalam menyelesaikan soal SPLDV (grafik, eliminasi, substitusi). Hal ini terlihat dari hasil tes tulis dan wawancara subyek VM, GTR dan SA yang tidak memenuhi aspek kelancaran (fluency), aspek keluwesan (flexibility), dan aspek kebaruan (novelty). Skor yang diperoleh subyek dalam tes tulis kurang dari 1,25 sehingga dalam hal ini peserta didik termasuk kategori tingkat "sangat rendah" dalam berfikir kreatif.

\section{KeSIMPUlan}

Berdasarkan hasil analisis dan pembahasan yang telah dilakukan oleh peneliti maka diperoleh kesimpulan sebagai berikut:

1. Peserta didik dengan AQ tipe climbers termasuk dalam tingkat "tinggi" dalam berfikir kreatif, dalam hal ini peserta didik mampu menjelaskan hasil pekerjaannya yang telah ditulis dengan lancar dan benar pada soal yang diberikan, peserta didik mampu memberikan dan menjelaskan beberapa alternatif jawaban yang ditulis, peserta didik

Copyright $\odot 2018$ Author [s]. This is an open-access article distributed under the terms of the Creative Commons Attribution License (CC BY). The use,

distribution or reproduction in other forums is permitted, provided the original author(s) and the copyright owner(s) are credited and that the original

publication in this journal is cited, in accordance with accepted academic practice. No use, distribution or reproduction is permitted which does not comply with these terms. 
mampu memberikan jawaban menggunakan caranya sendiri dengan tidak menggunakan metode yang biasa digunakan dalam menyelesaikan soal SPLDV (grafik, eliminasi, substitusi).

2. Peserta didik dengan AQ tipe campers termasuk dalam tingkat "rendah" dalam berfikir kreatif, dalam hal ini peserta didik mampu menjelaskan hasil pekerjaannya yang telah ditulis dengan lancar dan benar pada soal yang diberikan, peserta didik ada yang mampu dan ada yang tidak mampu memberikan dan menjelaskan beberapa alternatif jawaban yang ditulis, peserta didik ada yang mampu dan tidak mampu dalam memberikan jawaban menggunakan caranya sendiri dengan tidak menggunakan metode yang biasa digunakan dalam menyelesaikan soal SPLDV (grafik, eliminasi, substitusi).

3. Peserta didik dengan AQ tipe quitters termasuk dalam tingkat "sangat rendah" dalam berfikir kreatif, dalam hal ini peserta didik ada yang mampu dan ada yang tidak mampu menjelaskan hasil pekerjaannya yang telah ditulis dengan lancar dan benar pada soal yang diberikan, peserta didik ada yang mampu dan ada yang tidak mampu memberikan dan menjelaskan beberapa alternatif jawaban yang ditulis, peserta didik tidak mampu dalam memberikan jawaban menggunakan caranya sendiri dengan tidak menggunakan metode yang biasa digunakan dalam menyelesaikan soal SPLDV (grafik, eliminasi, substitusi).

Saran dari peneliti untuk guru, dalam meningkatkan kemampuan berfikir kreatif peserta didik hendaknya tidak hanya memperhatikan peserta didik yang termasuk tipe climbers yang sudah dapat mencapai kompetensi yang maksimal. Peserta didik yang termasuk tipe campers, hendaknya guru dapat mengembangkan strategi dan metode pembelajaran agar peserta didik dapat mencapai kompetensi yang maksimal. Peserta didik yang termasuk tipe quitters, hendaknya guru lebih memperhatikan dan membimbing agar peserta didik tidak merasa putus asa dalam menghadapi soal yang sulit dengan memberikan motivasi. Guru juga dapat memberikan latihan-latihan secara rutin dengan memberikan berbagai jenis soal yang dapat meningkatkan kemampuan berfikir kreatif peserta didik

\section{REFERENSI}

Al-habbah, 2015. Analisis Berfikir Kreatif Dalam Menyelesaikan Soal Luas Bangun Datar Siswa Kelas VII-G MTSN Karangrejo Tulungangung. Jurnal Pendidikan Matematika, 1 (5), (Online), (http://repo.iaintulungagung.ac.id/3089/1.pdf), diakses 02 Agustus 2018.

Budiarto, Mega Teguh. 2017. Profil Berpikir Reflektif Siswa Dalam Memecahkan Masalah Matematika Ditinjau Dari Adversity Quotient. Jurnal ilmiah Pendidikan Matematika, 1 (7), (Online), (http://jurnalmahasiswa.unesa.ac.id/index.php/mathedunesa/article/viewFile/22731/20840), diakses 28 Juli 2018.

Diana, Nida'u. 2009. Study Deskriptif Tentang Adversity Quotient Pada Siswa kelas Akselerasi di Sekolah Menengah Atas Negeri 1 Malang(SMAN 1 Malang). Jurnal Pendidikan Matematika, 1 (1), (Online), (http://etheses.uin-malang.ac.id/4384/1/04410009.pdf), diakses 11 Oktober 2018

Fauziyah, Isna Nur Lailatul. 2013. Proses Berfikir Kreatif Siswa Kelas X dalam Memecahkan Masalah Geometri Berdasarkan Tahapan Wallas Ditinjau dari Adversity Quotient (AQ) Siswa. Jurnal Pendidikan Matematika, 1 (1), (Online), (https://core.ac.uk/download/pdf/12347864.pdf), diakses 27 Juli 2018.

Moleong, Lexy J. 2011. Metodologi Penelitian Kualitatif Edisi Revisi. Bandung: PT Remaja Rosdakarya. Ningrum, Indri Aristya. 2016. Analisis Proses Berfikir Kreatif Matematis Peserta Didik Ditinjau Dari Adversity Quotient Kelas VIII Mts Muhammadiyah Bandar Lampung Tahun Ajaran 2016/2017. Jurnal pendidikan Matematika, 1(3), (Online), (http://repository.radenintan.ac.id/1608/1/ Ningrum.pdf), diakses 14 Maret 2018.

Siswono, T.E.Y. 2011. Level Of Students Creative Thinking In Classroom Mathematic. Education Research and Review, 6 (7), pp 548-553, ISSN 1990-3839, (Online), (http://www.academicjournals.org/ERR), diakses 12 September 2018.

Suastika, I Ketut. 2017. Mathematics Learning Model Of Open Solving to Develop Students' Creativity. International Electronic Journal Of Mathematics Education, 12(3), 569-577, e-ISSN: 1306-3030, (Online), (http://www.iejme.com/download/mathematics-learning-model-of-open-problemsolving-to-develop-students-creativity.pdf), diakses 28 September 2018

Supardi, U.S. 2015. Pengaruh AQ Terhadap Prestasi Belajar Matematika. Jurnal Formatif, 3(1):61-71 ISSN: 2088-351X, (Online), (https://media.neliti.com/media/publications/234974-pengaruh-adversityqoutient-terhadap-pre-e7aOfa22.pdf), diakses 01 November 2018.

Yamin, M. 2013. Strategi dan Metode dalam Model Pembelajaran. Jakarta: Referensi GP Press Group.

Copyright ( $\odot 2018$ Author [s]. This is an open-access article distributed under the terms of the Creative Commons Attribution License (CC BY). The use, 